\title{
Tanzania's community forests: their impact on human well-being and persistence in spite of the lack of benefit
}

\author{
Nicole Gross-Camp $^{1}$
}

\begin{abstract}
In this paper I describe the influence of community-based forest management (CBFM) on the well-being of local stakeholders in eight Tanzanian villages. The justification for this focus is based on the broad, international support for CBFM, support for its expansion within Tanzania specifically, and foundational belief that CBFM has the potential to provide significant social benefits to the communities in which it is practiced. Using a participatory video process, I developed a questionnaire to help quantify and qualify changes in aspects of well-being over a 10-year period, 2005-2015. These changes were based on individual responses but reflected changes in larger household units. Individuals given the questionnaire were selected following a wealth ranking process in which households were assigned, by a subselection of their community, a wealth category. This process also helped to identify current leaders and female-headed households in each village, groups that have been demonstrated to disproportionately benefit or bear the cost of other interventions. Households' wealth categories were found to be largely stable, with most remaining in the wealth category assigned in 2005 to 2015 with no significant difference between villages with or without CBFM. In contrast, current leaders were found to be more likely to increase in wealth and female-headed households, more likely to decrease. Two significant differences in CBFM and non-CBFM villages are reported: greater food insecurity and better water access in areas with CBFM. Focal group discussions of these results challenged the relevance of CBFM presence-absence in driving such findings, revealing a strong narrative of communitylevel support for CBFM by local stakeholders defined by greater control of their forest (and an ability to exclude outsiders), regular access to forest products, and pride in recognition for their conservation efforts (by other villages and the state).
\end{abstract}

Key Words: community forestry; participatory video; Tanzania; wealth ranking; well-being

\section{INTRODUCTION}

Forests are widely recognized for their environmental and social contributions to people and planet. In particular tropical forests play a significant role in the livelihoods of the rural poor through their provision of goods (food, medicine, and fuel) and services (moderating erosion, air quality, weather moderation). Historically such forests have been managed through centralized governmental institutions and at times to the detriment of local interests (Barrow et al. 2016). Indeed state institutions often justified their control and marginalization of local users by attributing the bulk of forest ecosystem loss to communities living in or near their boundaries. In response to the limitations of the strongly preservationist approach, governments began to shift toward decentralized management. Decentralization was characterized in principle by a return to greater local control and participation (but see Nelson and Agrawal 2008), and wider promise to deliver ecological and social benefits. These policies have spread widely across the developing world, applying to an estimated one third of the world's forests (Sunderlin et al. 2008) and including 35 of 51 countries in sub-Saharan Africa (Odera 2004).

Forest decentralization has been mixed in its ability to deliver its promised objectives. Barrow and colleagues (2016) describe the major limitations to decentralization's success as (1) its having largely been applied to low-value forests, (2) institutional and administrative impediments to local management under the pretext of making sure that the forest is "properly managed," and (3) local communities' lack of capacity to navigate the market for the sale of forest products. From an ecological perspective, the literature is more optimistic with a growing body of evidence demonstrating the ability of indigenous and local communities with strong tenure rights to manage their forests as well as or better than areas owned and managed by the state (see Porter-
Bolland et al. 2012, Patenaude and Lewis 2014, Seymour et al. 2014). If then, decentralization is to fully realize its potential, the evidence thus far implies a need to focus more explicitly on the social dimensions and to develop greater insight into how decentralization processes impact the communities that they were purported to empower.

Tanzania is one of the most biologically rich nations on Earth with approximately $51 \%$ (48.1 million hectares) covered by forests and woodlands (MNRT 2015), the bulk of which are located on village land (Blomley and Iddi 2009). Like many other developing nations in the late 1990s, Tanzania shifted from centralized forest control toward a more locally mediated process or participatory forest management (PFM). PFM objectives were threefold: (1) to improve local livelihoods, (2) to conserve and regenerate forests and forest resources, and (3) to promote good governance (URT 2013). By 2012, more than one fifth of Tanzanian villages were involved in varying stages of PFM (2285 villages; MNRT 2012). The continued expansion of PFM seems likely as is evidenced by its central place in Tanzania's forest law and policy as well as strength of externally funded in situ organizations, e.g., MJUMITA, Tanzanian Forest Conservation Group, Mpingo Conservation \& Development Initiative, supporting PFM expansion.

Despite the support for its expansion, the contribution of PFM to local communities' well-being has been poorly studied. Perhaps the most robust work to date is that of Persha and Meshack (2015) that examined the impact on communities of Tanzania's joint forest management, a type of PFM in which a community's forests are managed in conjunction with the government. Although they found strong positive impacts on local governance, particularly pertaining to the management of natural resources, there was no indication of livelihood impacts, despite this being a central 
justification for the national implementation of PFM. Persha and Meshack (2015) focused exclusively on objective indicators of well-being, namely income and assets. Although such indicators have been helpful in showing tangible changes, they are limited in their ability to reflect how people think and feel about their situations (more subjective aspects) and consequently how they respond to policy incentives and constraints (Scott 2012, Gurney et al. 2014). Conversely, ignoring objective aspects could overlook the tendency for people in harsh or deprived situations to adapt their preferences accordingly (Sen 1999). Therefore it is important to balance the inclusion of objective and subjective (how people think and feel about what they have and can do) indicators to more holistically describe well-being.

In this paper, I describe the impacts of community-based forest management (hereafter, CBFM) on peoples' objective and subjective well-being in eight Tanzanian villages. This research contributes to our understanding of the contribution of CBFM to the well-being of the stakeholders that it is intended to impact: local people. Furthermore, I explore reasons for CBFM persistence in light of a lack of explicit well-being benefit.

\section{METHODS}

Using a quasi-experimental design, four villages with CBFM were selected in the Districts of Kilwa and Rural Iringa and matched to four additional villages without CBFM on salient sociodemographic and environmental characteristics to give a controlimpact study (Keane, Bluwstein, Burgess, et al., unpublished manuscript). Two main methods were employed to facilitate an exploration of CBFM on well-being: a participatory video process and well-being questionnaire. Participatory video was utilized to develop well-being indicators that were locally relevant and allowed for a disaggregated view of communities, e.g., gender or wealth, based on previous research that indicates the limitations of using externally derived categories (Woodhouse et al. 2015) and need to understand differentiated experiences of well-being (Daw et al. 2011). The questionnaire was guided by the content of the participatory video process and facilitated an understanding of changes in household-level well-being over a period of 10 years. Further efforts were made to validate results, returning to the communities at the end of the study period to discuss and collect additional information through focal group discussions.

\section{Defining well-being through a participatory video process}

I utilized a participatory video process (PV) to facilitate an understanding of locally relevant well-being indicators. The Swahili, hali ya maisha, was used for well-being, translating as "conditions of life." PV was employed in four of the eight villages, two with and two without CBFM. Villages were selected based on initial consultations with the local village government authorities and a perceived willingness and interest of the community to engage with this methodology.

Participatory video is a methodological approach in which a group of local people generally not experienced in filmmaking create a video on an issue of interest or concern to them, deciding what is important to include and how they wish to be represented. Historically, PV has been used in development projects as a tool to engage and empower often marginalized groups on an issue of social concern (Snowden 1998). I selected PV based on its potential to help participants describe, explore, and clarify what well-being meant to them (Garrett 2010). Furthermore, I selected $\mathrm{PV}$ as an alternative to more traditional methods based on its ability to involve and solicit input from audiences both within and beyond the community in which the film is created. For example, the screening of footage within a different community can act as a springboard for discussion amongst other interested stakeholders.

The PV participants were selected through a series of steps in each of the four villages in which PV took place. First, I met with the village council, a group of locally elected representatives from within the village, to describe my overall research objectives and more specifically participatory video process. I outlined general characteristics needed in the participants to be selected including an openness to the perspectives of others and an ability to represent the broader community. Additional attention was given to political affiliations, age, gender, and leadership roles, in particular on the forest or environmental committees. I returned to each village at its next village assembly meeting where I repeated this process. Village assemblies are open to anyone in the village, occur approximately four times a year, and are the main means of communicating information and deliberating community interests. At this meeting the community generated a list of $12-$ 15 individuals from which $8-10$ were selected to participate through a majority vote. A third meeting was then scheduled to further discuss the PV process, participation allowance, and an agreed start date with the selected participants.

The PV process occurred over an initial seven-day period in which participants received technical training followed by a series of activities that explored well-being and assisted in the creation of a storyboard and ultimately, film. Rough cuts of video were screened in the evenings in a public area in the village and encouraged input from a broader audience for the consideration of the PV group. Although I facilitated the PV process and mandated a focus of the group's video on well-being, it is important to note that I did so employing dialogic techniques in which divergent views were encouraged and respected in a noncompetitive, explorative manner. For example, one exercise entailed participants taking pictures of three things that constituted well-being and three things that constituted ill-being. These images were then projected and discussed. Later methods were deliberative in an effort to encourage participants to reflect and describe their reasons for selecting (or ignoring) indicators of well-being. For example, after brainstorming all aspects of what constituted a good life in their village, participants were asked to create themes of well-being and select the top five themes for their communities. Themes were ranked in order of importance, with equal rankings being allowed.

\section{Measuring changes in household-level well-being using a questionnaire}

Questionnaires were developed after and guided by the themes arising from the participatory video process, as well as by a questionnaire to describe well-being changes in the wildlife management areas of Tanzania ${ }^{[1]}$, a questionnaire to assess wellbeing in a Tanzanian pastoralist community, and the multidimensional poverty index (Alkire and Santos 2010). An initial wealth ranking exercise was carried out for all households in each study village. Wealth ranking was organized in conjunction with the village council with 6-8 representatives from the community selected based on their familiarity with the 
village's residents. Participants explored the activities of four distinct wealth groups (very poor, poor, normal, and wealthy). For example, what would a typical poor household in your village do for a living, spend money on, be able to afford? Once the distinctions of each category were agreed, participants went through the list of households from the 2012 Tanzanian population census assigning a wealth category for each household in 2005 and 2015. Female-headed households and households with a current leader present were also noted. Households for the well-being questionnaire were then selected using a combination of purposive (i.e., leaders) and stratified random sampling (i.e., using their 2015 wealth rank status). One adult member of each household was interviewed alternating between genders.

Forty individuals, stratified by leadership, wealth, and gender in each of the eight villages completed the questionnaire $(\mathrm{N}=320)$. Three field assistants were employed to assist in the collection of the well-being questionnaires and involved from the inception of its implementation, e.g., translation from English to Swahili. Following piloting of the questionnaire and assurances that questions were being interpreted correctly, assistants continued independently. Questionnaires were collected using ODK freeware (Brunette et al. 2013) and reviewed regularly for data collection quality.

The questionnaire included questions under the thematic areas of household demographics, land, livestock, livelihoods and assets, forest and forest use, including an additional section on CBFM formation and management for CBFM villages only, health, hope, and several subjective statements concerning one's ability to make decisions that may impact their lives (Appendix 1). The bulk of the questionnaire comprised closed questions with a few open-ended questions to clarify people's closed responses. Several questions were time dependent to capture changes in wellbeing at the approximate beginning of CBFM (2005) and present day (2015). Therefore only households that had been present in the village since 2005 were eligible. For example, does your household own any land now on a customary basis (2015) or did they in 2005? Time was taken at the inception of each interview to ensure that the respondent was able to think back accurately to 2005 when Tanzania held presidential elections, which greatly facilitated respondents' recall. However, if a respondent struggled with this reflection, the interview was terminated.

\section{Group discussions}

Three group discussions were conducted in each of the eight villages consisting of six to eight individuals per group ( $N=24$ groups). Groups were composed of all men, all women, and representatives of the committees responsible for the management of the community forest or, in the case of villages without CBFM, the forest and village land more generally. Following a description of the results stemming from the participatory video and well-being questionnaire, discussions were semistructured and served to explore (1) the group's perception of CBFM particularly in relation to other forest types on their village land, (2) response to the lack of impact of CBFM on household's well-being as indicated by the questionnaire results, and (3) the maintenance of CBFM in the absence of explicit benefits. In the case of villages without CBFM, discussion focused more on their knowledge of CBFM and attitude toward it in relation to their own forest management practices.

\section{Data analysis}

The participatory video content was analyzed using three main components of the PV process: photo elicitation in which respondents were asked to photograph and discuss image of welland ill-being, the top five well-being themes selected during a deliberative exercise, and the content of the film produced. Additional contextual and ethnographic information was extracted to support and interpret the results stemming from the questionnaire. Descriptive and other statistical analyses of the wealth ranking and well-being questionnaire data were done in R (RStudio_Team 2015) using the lme4 (Bates et al. 2015) and ordinal libraries (Christensen 2015).

\section{RESULTS}

\section{Defining well-being through a participatory video process}

Four films were produced describing what constitutes a good life for each respective village (The films are freely available online with the consent of the communities here: https://www.youtube. com/playlist?list=PLTcEN70LB3-XxQjaX2xytjNyt1RJbob5W). Films and participatory exercises were coded for themes resulting in nine thematic well-being areas including land (agriculture), forest, education, infrastructure, livestock, water, small businesses, weather/climatic changes, and health. There was little distinction in the content and context between villages with and without CBFM with all emphasizing the importance of agriculture, forest, and education. Agriculture and forest feature prominently in people's dialogue focusing predominantly on the tangible uses of these areas but also reflecting ecosystem processes like transpiration and climate control.

The land is everything. Everything follows the land. A good example is farming. I can cultivate and get maize to feed my family, also I can make bricks to construct my house from the land. I can plant trees for my children's future use and they will know the benefit of the environment to our lives, [Kilambo PV participant].

The environment provides us with firewood for cooking and timber for building our homes. There is a good exchange of air due to the presence of the trees, which attract rainfall and helps in our agricultural activities, [Kiwawa PV participant].

Education is described more as a means to a better life and extended beyond the classroom setting. For example, Mchakama residents described education as "the key to their future life" that brings understanding and knowledge through which children may "go to college and become doctors or teachers and obtain a good life." Education extends, however, to the development projects that come to a village such as the One Acre Fund that provided agricultural support and small loans for the purchase of solar lamps. Similarly, education may be found in religious life providing moral guidance to adults and children alike.

There is a pervasive tension in the way people present modern versus traditional ways to outsiders, with strong pressure to present to outsiders (like me and my assistants) that the modern way is the better way. This tension was expressed in several facets of people's lives in particular education, agricultural and religious practices with the adoption of modern practices being equated with an improvement in well-being. For example, in Kilambo participants described their (HeHe people) use of ritual to 
"appease their ancestors" who were angry because of the villagers' cutting of the forest. These rituals involved the slaughtering of a black cow in the forest, which was then consumed along with water that had been placed in a ritualized calabash and left in their ancestral graveyard for a defined period. After performing these rituals, the rains returned and lasted five days. In recounting this history, participants indicated that this was their belief but stated they now know that this is untrue and "have a better understanding of the biophysical processes." Participants further described their ability to pray for rain through other means, e.g., in the church, replacing traditional rituals and the physical interactions with the forest and broader environment that they mandated.

Similarly, those that resist modernity are labelled as "backwards" and often pressured to change. For example, in Kinywang'anga participants constructed a small skit describing the resistance of a household to modern agricultural practices that involved the use of a rope to guide planting, use of hybrid seeds, not mixing seeds in the same planting hole, and use of chemical fertilizers. In the skit one resident that uses these practices thinks to herself how best to bring this method of agriculture to her resistant neighbor. She thinks about his stubbornness, being related to his tribal affiliation, and decides to ask the agricultural extension officer to approach him instead. The officer approaches him, indicating that his yield is insufficient because of poor agricultural practices and encourages him to be more like his neighbor who employs more modern practices. The neighbor is suspicious that the success of the woman is in fact due to her being a "witch," to which the officer responds by bringing the neighbor into the discussion. Although the scenario is clearly contrived and a gross simplification, it is illustrative of how new ideas are transmitted (or rejected) by these communities. On the one hand, the woman's adoption of these agricultural practices is good for her, providing her with greater crop yields, but there are equal and opposite dangers, e.g., increased costs for inputs in purchasing seed and fertilizers, and social perception of being a witch.

\section{Well-being questionnaire}

A total of 2977 households from 7 villages were assigned wealth ranks for 2005 and 2015. The eighth village, Ruyaya, was excluded because of a corruption of the wealth ranking data. The majority of households remained in the wealth rank category assigned to them in 2005 to 2015 regardless of village type (CBFM and nonCBFM; Fig. 1). Cumulative link mixed models using Laplace approximation (Christensen 2015) showed no significant differences by village type (Table 1), but indicated that femaleheaded households are more likely to decrease in wealth, and leaders more likely to increase (CLMM: $-0.86 *$ wealth rank \pm 0.18 , $\mathrm{z}=-4.71, \mathrm{P}=<0.001$ and $1.03 *$ wealth rank $\pm 0.24, \mathrm{z}=4.26, \mathrm{P}$ $=<0.001$, respectively; Tables 2 and 3 ).

Profiles of respondents in CBFM and non-CBFM villages were similar and included approximately $60 \%$ men and $40 \%$ women. The majority of individuals were married $(80 \%)$ with a smaller proportion being female-headed households $(27 \%)$. Respondents largely reported no more than three livelihoods $(78 \%)$ with their main livelihood being agriculture followed by livestock or small business, and household consumption of items collected from the forest (Fig. 2). Respondents in areas with and without CBFM were generally similar with very few differences revealed in the questionnaire. Most respondents reported at least one member of their household had completed at least five years of education $(79 \%)$, with slightly fewer having completed secondary school $(62 \%)$ and very few higher education $(6 \%)$. Less than 10 households had electricity though the percentage of households using solar lighting (or electricity) increased from 3.1 to $18.4 \%$ in 2015. All but a single respondent reported the use of charcoal or fuelwood for cooking. Household size increased from 4.8 to 5.5 people in 2015 with slightly larger household sizes being reported in non-CBFM villages, 6 versus 5 .

Fig. 1. The change in wealth rank from 2005 to 2015 where " 1 " is the poorest and " 4 " is the least poor, $\mathrm{N}=2977$ households. The proportion of households shifting up (or down) in 2015 is indicated by the shaded area on top (or below) a given bar. For example, in the CBFM graph rank 3, a small percentage of households shifted down to ranks 1 and 2, the majority remained at rank 3 , and a small percentage shifted up to rank 4. In contrast in the non-CBFM villages, a few households shifted down to rank 2 , most remained at rank 3 , and slightly more shifted up to rank 4

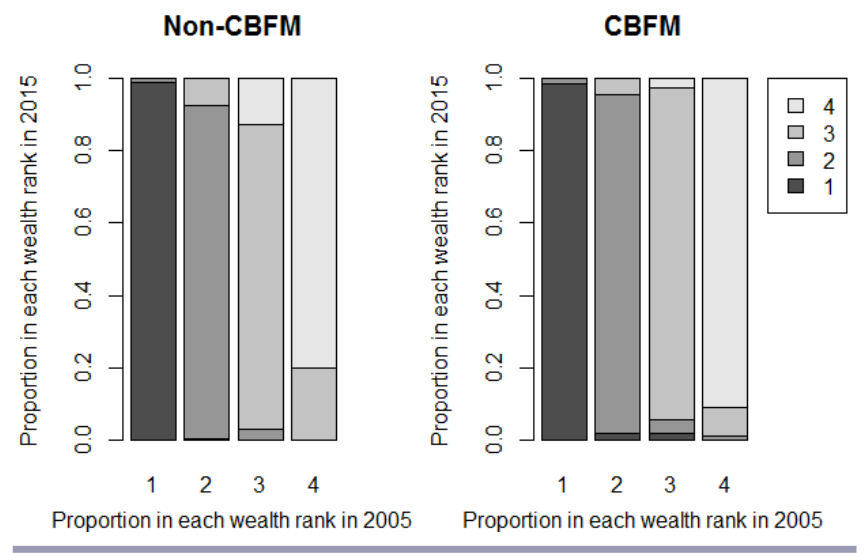

Table 1. Results of a cumulative link mixed model of changes in wealth rank category in 2005 and 2015 by village type (cbfm) and interactions. Village was included as random effects to control for nonindependence of wealth ranks by village. The intercept is the mean value for wealth rank in 2005 for wealth rank category 2 . The estimate for wealth rank in 2005 for wealth category 3 (wri053) is the mean difference between the intercept and wri053. Similarly the estimate for wealth rank in 2005 for category 4 (wri054) is the mean difference between the intercept and wri054.

\begin{tabular}{lcc}
\hline \hline Fixed effects & Estimate (SE) & z-value \\
\hline intercept & $9.16(0.76)$ & $12^{*}$ \\
wri053 & $15.38(0.86)$ & $17.98^{*}$ \\
wri054 & $19.22(1.41)$ & $13.66^{*}$ \\
cbfm & $0.19(0.93)$ & 0.21 \\
wri052:cbfm & $-0.78(0.91)$ & -0.86 \\
wri03:cbfm & $-1.37(0.97)$ & -1.42 \\
wri04:cbfm & $0.76(1.49)$ & 0.51 \\
& & \\
Random effects (N) & Variance (SD) \\
village (8) & $0.14(0.37)$ & \\
\hline
\end{tabular}

* $\mathrm{P}=<0.001$ 
Table 2. Results of a cumulative link mixed model of changes in wealth rank category from 2005 and 2015 by gender (female). Village was included as random effects to control for nonindependence of wealth ranks by village.

\begin{tabular}{lcc}
\hline \hline Fixed effects & Estimate (SE) & z-value \\
\hline intercept & $8.65(0.47)$ & $18.52^{*}$ \\
wri053 & $14.40(0.54)$ & $26.86^{*}$ \\
wri054 & $20.15(0.70)$ & $28.61^{*}$ \\
female & $-0.86(0.18)$ & $-4.72^{*}$ \\
& & \\
Random effects (N) & Variance (SD) & \\
Village (8) & $0.25(0.50)$ & \\
$* \mathrm{P}=<0.001$ & & \\
\hline
\end{tabular}

Table 3. Results of a cumulative link mixed model of changes in wealth rank category from 2005 and 2015 by leadership status (leader). Village was included as random effects to control for nonindependence of wealth ranks by village.

\begin{tabular}{lcc}
\hline \hline Fixed effects & Estimate (SE) & z-value \\
\hline intercept & $8.69(0.47)$ & $18.62^{*}$ \\
wri053 & $14.42(0.53)$ & $26.99^{*}$ \\
wri054 & $20.10(0.70)$ & $28.82^{*}$ \\
leader & $1.03(0.24)$ & $4.26^{*}$ \\
Random effects (N) & Variance (SD) & \\
Village (8) & $0.26(0.51)$ & \\
\hline
\end{tabular}

$* \mathrm{P}=<0.001$

Fig. 2. Livelihoods activities in rank order of importance. The majority of households reported no more than three livelihood activities (78\%) with no difference between community-based forest management (CBFM) and non-CBFM villages. Reg (ularly) waged refers to an employee who received a regular (monthly) wage, e.g., teacher in a school or employee of a business.

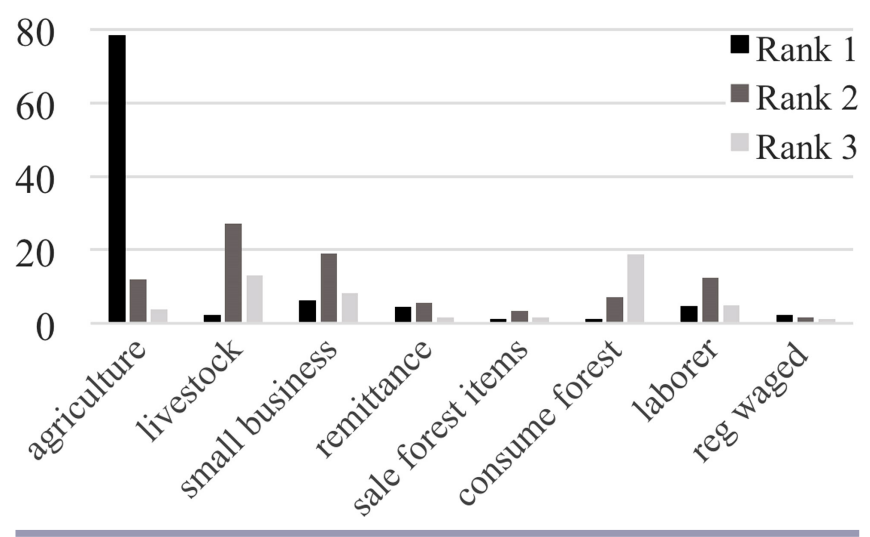

The majority of households reported some customary ownership of land $(96 \%)$ with fewer renting $(24 \%)$. Land size did not vary by village type (mean $=7-8$ acres/household) but with more households in areas with CBFM renting significantly smaller areas of land, 3 versus 5 acres, respectively $\left(F_{176}=4.29, P=0.042\right)$. There was an increase 2005-2015 in the proportion of households reporting difficulty in their ability to feed their family using income or food generated from their land with significantly more reporting difficulty in areas with CBFM (Table 4). Villages provided similar reasons for this shortcoming ascribing it to less predictable rainfall patterns, limitations of their physical ability because of health or age, and a high cost of chemical inputs. Those reporting an improvement in food security attributed it to access to better agricultural practices, namely the use of oxen to plough or chemical inputs. Water access was the one item reported as having improved significantly more in areas with CBFM (CLMM: $1.67 \pm 0.44, \mathrm{z}=3.83, \mathrm{P}=<0.001$; Fig. 3).

Table 4. Results of a generalized linear mixed model of changes in perceived food security in 2005 to 2015 by village type (cbfm) and interactions. The model indicates that food security in 2015 was significantly worse in both areas, but more so in areas with cbfm (food security 2015:cbfm). The lack of significance of cbfm indicates that there was no difference in food security in areas with and without CBFM in 2005.

\begin{tabular}{lcc}
\hline \hline Fixed effects & Estimate (SE) & z-value \\
\hline intercept & $0.59(0.44)$ & 1.35 \\
food security 2015 & $-1.02(0.29)$ & $-3.49^{*}$ \\
cbfm & $0.50(0.61)$ & 0.83 \\
food security 2015:cbfm & $-1.52(0.42)$ & $-3.64^{*}$ \\
& & \\
Random effects (N) & Variance (SD) & \\
individual id (318) & $0.89(0.94)$ & \\
village (8) & $0.58(0.76)$ & \\
\hline
\end{tabular}

$* \mathrm{P}=<0.001$

Fig. 3. People's perception of changes in water access from 2005 to 2015. Areas with community-based forest management (CBFM) reported significantly greater improvement in contrast to areas without CBFM.

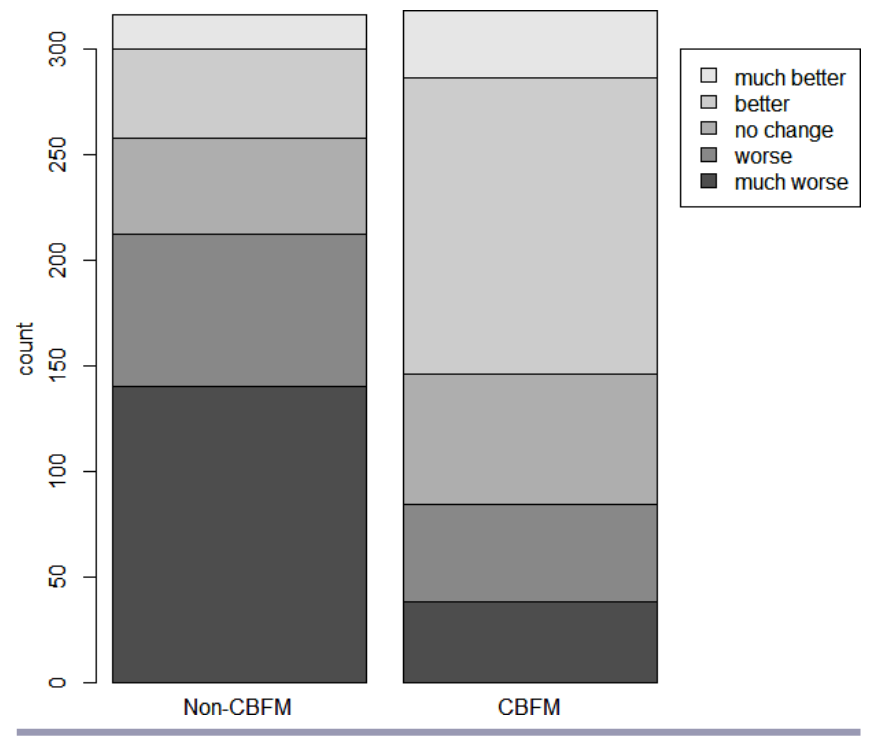


Additional questions asked only of respondents living in CBFM villages indicated their strong awareness of and support for CBFM presence $(\mathrm{N}=160)$. The vast majority of respondents were aware that there was an established community forest in their village $(92.2 \%)$ with slightly less $(89.5 \%)$ being familiar with its locational boundaries. Approximately $63 \%$ of respondents felt sufficiently informed about the management of their community forest. Most people knew who their CBFM leaders were (range 79.5-92.5\%), but fewer felt able to exert influence on these leaders in the management of the CBFM (54.1-84.6\%). Respondents largely remained supportive of the CBFM from its inception to its current state though one village, Mandawa, showed a notable decrease in 2015 (Table 5). Only 17 respondents indicated that they or someone in their household receive employment or another kind of financial benefit from the CBFM.

Table 5. The proportion of respondents that supported the community-based forest management (CBFM) at its time of formation and presently (in 2015).

\begin{tabular}{lcc}
\hline \hline & \multicolumn{2}{c}{ Support of CBFM $(\%)$} \\
\cline { 2 - 3 } Village name & At inception & At present \\
\hline Kinywan'ganga & 92.3 & 92.3 \\
Kitapilimwa & 97.3 & 97.4 \\
Mandawa & 93.9 & 72.7 \\
Mchakama & 88.9 & 88.6 \\
\hline
\end{tabular}

\section{Group discussions}

\section{Perceptions of CBFM in relation to other forest}

Initial questions focused on people's understanding of CBFM and the management of forests more broadly located on or adjacent to their community's land. Villages with existing CBFM were more familiar with the central tenets of CBFM including the forests being legally owned by the community and community's ability to retain up to $100 \%$ of the profits derived from the sale of items being harvested from it or of fines imposed for illegal use. Female and male groups were similarly knowledgeable with environmental committees having the most detailed understanding of CBFM. Although some members involved in the CBFM management spoke of ecosystem services, the majority focused on its utility as a future resource and means of securing its use for a given village. One woman in Mchakama stated the following:

\section{We closed the forest [and created the CBFM] because we saw there was too much destruction there and we want development [i.e., money]. . but, even if it [i.e., timber sales] doesn't come, it is our resource, we will keep it and use it. It [being a CBFM] helps other villages know that area is Mchakama's and be frightened to enter it because they know that it is protected by the law.}

Groups were also asked to describe the different forest areas in their villages and respective management of those forests. All villages retain some "open" forest, areas that fall on village land and are de facto utilized by villagers but de jure owned by the state. These areas were described as free access areas and, particularly in the case of communities in Kilwa, were important sites for the collection of household subsistence needs, e.g., firewood. "If we need anything from the [open] forest, we just go there to collect it," [Mandawa village, Kilwa, men's group].

Two villages in Iringa, Kitapilimwa and Kinywa'nganga, abut an area under joint management with the government (JFM); these communities described management and access in these JFM forests differently than that of their CBFM with greater restrictions on access and fewer benefits. For example, one participant in the male group from Kitapilimwa described the value of the CBFM much like that of the open forest to villages in Kilwa.

There is local medicine there [in the CBFM] that we can
go and collect when we need it. . previously the forests
were very degraded but now it is recovering and we are
able to collect things there like firewood and mushrooms.

Response to the results from the questionnaire

No group perceived CBFM presence as a driving factor in the deterioration of food security as suggested by the questionnaire results. Groups largely attributed food insecurity to a lack of rainfall suggesting that topographical differences in where a village is located was likely more important than constraints placed on land use due to CBFM presence. Similarly, greater water security in CBFM sites did not seem to translate to differential treatment from external organizations or clear geographic advantages, e.g., proximity to a river or other reliable water source. All Iringa villages had had some kind of external intervention from humanitarian or district-level agencies to support the digging of wells. In contrast none of the Kilwa sites indicated such support. Despite such interventions, villages stated that they still struggled for water access, especially during the dry season, because of reoccurring issues with the donated water system, i.e., pump failure and the placement of pump for water access in the wet season means no water in the dry. Last, three villages described greater year-round access to water with two villages (Kitapilimwa and Mchakama both with CBFM) having rivers running through their land and a third, Ruyaya (non-CBFM), being in close proximity to the sea. Although the sea water is not potable, Ruyaya residents described their ability to dig shallow wells to access fresh or mildly saline water. Some villages demonstrated an understanding of forest cover and water retention but did not attribute changing water availability to CBFM presence as a major factor. For example one male respondent from Mchakama stated, "Water will become a problem in 10-15 years to come because of an increase in tree cutting along the river." Similarly, the environmental committee in Kinywa'nganga described the importance of forest generally in helping to regulate climate.

Village support of CBFM in the absence of well-being benefits Following an exploration of questionnaire results and subsequent reactions, groups were asked to describe why, in the absence of a contribution to household-level well-being, did they continue to engage with CBFM? For villages without CBFM, I explored their current forest management practices and perceived potential benefits of having a CBFM. Three main reasons were provided with slight differences in the districts. Foremost, groups indicated that CBFM improved a village's ability to control the forest. All CBFM groups (and even some without CBFM) described CBFM as giving them more authority, for example, to issue fines for illegal 
activities, patrol, and more broadly, regulate use. The environmental committee in Kitapilimwa (Iringa) described the greater security of the CBFM with "open" forests being more dangerous because of a lack of respect and recognition of the village as an authority there. The committee in Mandawa (Kilwa) echoed this sentiment in the following statement: "Forests are important but the CBFM is more important because it is ours and we control what happens there."

In contrast communities without CBFM described considerable difficulty in controlling forest activities on their village land. In Ruyaya (Kilwa) all three focal groups expressed deep concern for the unregulated activities occurring in their forests.

\section{We do not like that outsiders come and cut timber or burn charcoal, but what can we do? We spoke with the Ward Executive Officer [authority above Village and below District] but there is no response. They [District and Ward officers] know that there is insecurity, they come here in their cars and can see what is happening [illegal extraction] but do nothing. . . We need their support because some of the people doing illegal activities can be dangerous [i.e., carry guns] and we do not have an ability to deal with this, [Ruyaya, environmental committee].}

Similarly, a participant from the men's group in Mgera (nonCBFM in Iringa) stated, "Creating [a CBFM] is a very good thing because the community will have power over it in protection and it will prevent others from randomly cutting trees and burning charcoal." These sentiments suggest that CBFM not only provides greater control by the community in which it is located but also beyond, serving as a deterrent and making it more difficult for outsiders to access these areas.

Access to forest products was also commonly described as an important value of CBFM. For Iringa villages this was reflected in items collected for household use as well as communal activities.

The CBFM forest is more important to us [than other forests in the community] because it is ours. We all benefit from it like the collection of mushrooms but also for building materials for community things, (Kitapilimwa, women's group).

In contrast CBFM was perceived to restrict household-level use in Kilwa with groups describing them as no-go zones. Instead, these groups opted to collect household resources from the open forest and agricultural land. Both Kilwa and Iringa villages, however, indicated that CBFMs were largely used to benefit communal needs. In Kinywa'nganga (Iringa) the female group described a time when many members of their village were struggling with hunger. The community met and decided to produce some charcoal from their CBFM, which was then sold to purchase additional food (see also Beauchamp and Ingram 2011 for a similar example). In Kilwa, however, CBFM has followed a model of sustainable timber harvesting of Forest Stewardship Certified (FSC) wood; this model stems from the activity of the Mpingo Conservation and Development Initiative (MCDI), the main CBFM advocacy organization and NGO in the area. In Kilwa villages, groups described the financial benefits (largely anticipated) that would support communal activities. These sales, unlike those described in Iringa, were almost entirely dependent on MCDI, an external organization including achievement of FSC status, location of timber buyers, and even timber harvesting. Village members seem aware of these potential limitations but are not deterred by them. Indeed their attitude reflects an understanding that big financial benefits may never manifest. Nonetheless the presence of the CBFM is minimally perceived to secure a village's ability to access resources from the forest in the future.

Similarly, when I asked Kinywa'nganga about their use (and potential overuse) of their CBFM the environmental committee responded,

\section{We limit the amount of wood that is burned to produce charcoal and no longer allow outsiders to do so. When the CBFM was established, we knew that we'd have to wait sometime before we could benefit from it. The forest had been badly degraded. We had to wait until it had regenerated a bit. Now, we burn charcoalmore selectively and use the profits to help ourselves.}

Indeed, Kinywa'nganga's charcoal production from the CBFM over the past three years has enabled the village to build a village office, teacher's house, and dispensary (ongoing).

Third, groups described a deep sense of pride in having a CBFM. In Mandawa the male group stated, "We feel proud [of the forest] as even our grandparents guarded it for us. We are replanting trees and want to increase the area of the CBFM for future generations." This sentiment is similarly reflected by the Kitapilimwa environmental committee,

\begin{abstract}
We are proud of our management, because we protect our forest for future [generations]. We are proud of our forest $[\mathrm{CBFM}]$ because we get a lot regardless of the current benefits we get, forest fruits etc. Other villages see what we are doing and we feel good about that.
\end{abstract}

\section{DISCUSSION}

Villages with and without CBFM were found to be more similar than different based on the defined well-being characteristics measured by the questionnaire. Despite the paucity of significant differences, communities with CBFM indicated an awareness of and strong support for these management structures begging the question of why, in the absence of pronounced benefit, were the CBFMs being maintained?

One potential explanation for the perpetuation of CBFM may be driven by the involvement of external institutions (Shackleton et al. 2002, Mahajan and Daw 2016). The formation of Tanzania's community forests has been predominantly driven by externally funded institutions and in particular the governmental aid agencies from Finland, Denmark, and Norway. The villages in Iringa were some of the first CBFM sites (MEMA project) established in the late 1990s by monies received from the Danish government. Sites were selected based on the rapid deforestation rates in these areas and potential for CBFM to facilitate their regeneration (Blomley and Iddi 2009). Sites were relatively small (2600 ha on average) and anticipated to earn between US\$540 720 per year, though this has never manifested. In contrast, the development of CBFM in Kilwa was based on its relatively pristine forest condition and potential to enter the sustainable timber market with FSC certified wood. The in situ, 
nongovernmental organization Mpingo Conservation and Development Initiative has been working in this area since 2004. MCDI remains an active part of CBFM in the Lindi Region (including Kilwa) often working in conjunction with other partners including community-based organizations. Although initially quite similar in size to the MEMA initiatives, CBFM sites supported by MCDI have grown considerably. In 2015 the CEO indicated the intention to focus on the formation of larger CBFMs of at least 2000 ha in size (Jasper Makala, personal communication, May 2015). This decision was based largely on financial viability; larger CBFMs enable harvesting at regular intervals of a quantity that is desirable from a buyer's perspective. Investment from the standpoint of MCDI and their funders is not insignificant (MCDI 2015) and undoubtedly plays a part in the perpetuation of CBFM in this area. MCDI continues to support the formation of smaller sites of high ecological importance though its ability to do so in the absence of external support is a significant challenge. In contrast, sites in Iringa are less actively supported and, after an initial three-year phase in which the CBFM was legally established and basic management techniques transmitted, have predominantly been left on their own. Perhaps then what is so remarkable is that these smaller, less well supported CBFMs seem to play such an integral part of villagers' lives.

A second potential reason for the perpetuation of CBFM may be that a smaller group of individuals are capturing the benefits but in a way that does not cause objections from the larger community (see for example Rao and Ibanez 2001, Lund and Saito-Jensen 2013). The finding that leaders were more likely than other households to increase in wealth is perhaps indicative of a broader phenomenon not unique to CBFM (Ribot 2004, World Bank 2008). Discussions within the focal groups described the tendency of leaders to be selected as, "an example of their community" and "hard-working with a creative mind." Additional discussion defined leaders as intelligent, better educated, and someone to emulate and aspire toward. Leaders were described as having greater access to meetings and training sessions in which they would receive knowledge that would, in turn, enable them to better their quality of life (and often income) in the future. More immediate benefits were also obtained through their receipt of a meeting stipend. The men's group in Mgera (Iringa) shared a Swahili proverb in explaining their perceptions of elite capture: Huwezi kutoa boriti kwenye jicho ka mwezako kabla hujatoa kibanzi kwenye jicho lako, "You can't remove a pierced object from someone else's eyes while you have it in your own, remove yours first then remove others." They explained this proverb to mean that although leaders sometimes take advantage of their power and benefit beyond what the community deems acceptable, some people may take advantage of this while others will speak out against it. All groups with the exception of the environmental committee in Mandawa described leaders' benefits without resentment, implying general acceptance of these perks of leadership. The Mandawa environmental committee implied leaders gained their wealth through corruption and was therefore not acceptable. Interestingly this lack of trust is reflected in the substantial drop in support of the CBFM in 2015. This deviation is also an important reminder that elite capture is relative and what is tolerable in one community may not be in another (Brown and Lassoie 2010).
Additional reasons for CBFM's perpetuation were described by the focal group discussions including communities' perception of greater control, access, and recognition. The role of control of the forest (and right to exclude) as well as access to forest products features prominently in the property-rights framework developed by Schlager and Ostrom (1992; see discussion of access and withdrawal). These views are perhaps attractive in their alignment with CBFM's foundational philosophy of providing social benefits but should be interpreted with caution. For example, in their review of 13 case studies of natural resource management, Shackleton and colleagues (2002) described the tendency for a state to provide benefits, like control of a small forest area and access to nontimber forest products, as an incentive for communities to cooperate with other initiatives, like state- or jointly-controlled forests, in which access is entirely restricted and local control, absent. Discussions with the study villages suggest that although communities derive some village-level benefits from their CBFM, they are denied access to larger state- and jointlymanaged forests and in some cases, even contribute their labor with little or no compensation for its protection. This is not to deny or belittle communities' support and indeed, benefits derived from their CBFM but rather to put it in perspective. In Iringa, villages with CBFM are perhaps at a slight advantage over their neighbors without such, but unlikely to ever be more than a small (but significant) supplement to their communal lives. In contrast the CBFM in Kilwa has taken a very different approach, targeting large tracts of relatively pristine forest and high-value timber. These larger CBFMs hold the potential to significantly contribute to a community's income as is demonstrated in the case of Nanjirinji village where the establishment of a 60,000 ha CBFM has enabled the village to rapidly develop infrastructure. But what of our more modestly sized study villages whose lands are unable to support such large CBFMs and/or are unlikely to provide timber (as in the case of Iringa)? In her recent plenary lecture at the Association for Tropical Biology and Conservation 2016, Professor Karen Kainer said, "It is not a perfect world but it [CBFM] may be the better option [when compared with other top-down initiatives]."

Last, given the described value of CBFM it is perhaps worth reflecting on non-CBFM community response and interest in establishing their own CBFM. Although Tanzania is widely perceived to have one of the most advanced and progressive legal frameworks for participatory forest management in sub-Saharan African (Mustalahti and Rakotonarivo 2014), the bureaucratic hurdle to establish a CBFM remains high for local communities. Ignoring a community's need for a basic understanding of CBFM governance and management, villages are severely limited in their ability to navigate the legal process of establishing a CBFM; indeed, no village has ever done so of their own initiative without significant support from an external organization. Currently, villages are required to produce a land use plan (LUP) prior to its allocation of land, e.g., as a CBFM or otherwise (URT 2007). LUPs are typically financially expensive, requiring technical expertise that villagers lack, and subsequently favors the interests of powerful (and often external) actors (Makwarimba and Ngowi 2012). This places the work of NGOs like that of MCDI and accessibility of CBFM to any village sharply in focus. On the one hand organizations like MCDI are likely key in the establishment 
of CBFM in a given village, perhaps even more so if the CBFM is to develop a plan to extract timber sustainably. MCDI's CEO indicated that for the first time since their operation in Kilwa, villages are now approaching them for assistance in the establishment of a CBFM (Jasper Makala, personal communication, June 2016). MCDI is now in a position of having to turn away villages in part because of their limitations as an organization but undoubtedly also a reflection of the ability of the CBFM to support sustainable forestry, the way in which MCDI has been able to attract funding as well as contribute to its income and sustainability as an organization. In short, the expansion of CBFM and potential contribution to villagers' quality of life mandates greater attention and commitment from the Tanzanian government to reduce the burden of CBFM establishment, i.e., LUP, and attention to villages with smaller forests that are unlikely to provide resources beyond the village in which it sits.

${ }^{[1]}$ http://www.ucl.ac.uk/pima/

Responses to this article can be read online at: http://www.ecologyandsociety.org/issues/responses. $\mathrm{php} / 9124$

\section{Acknowledgments:}

This research was supported by an early career research fellowship (FELL-2014-101) from the Ecosystem Services for Poverty Alleviation programme funded by the Department for International Development (DFID), the Economic and Social Research Council (ESRC), and the Natural Environment Research Council (NERC). This study was complementary to a larger ESPA project, "Poverty and Ecosystem Impacts of Tanzania's Wildlife Management Areas" (PIMA/ NERC grant NE/L00139X/1), from which many of the methods were emulated or adapted including site matching (Aidan Keane), wealth ranking (Jens Fris Lund), and the well-being questionnaire (Katherine Homewood). I would like to extend my deepest gratitude to my field manager, Lasima Nzao whose efforts made this research possible. I am equally indebted to Katherine Homewood, Neil Burgess, and Adrian Martin for their guidance and support throughout. A heartfelt thanks to Aidan Keane who provided extensive statistical support with grace and patience. Additional thanks are extended to my field assistants, Rozina Paschal and Peter Paul, whose company and laughter made light of heavy work. Finally, I thank the villages and villagers whose acceptance of our presence and willingness to engage with this research helped guide our conclusions and insights. Nashukuru sana.

\section{LITERATURE CITED}

Alkire, S., and M. E. Santos. 2010. Acute multidimensional poverty: a new index for developing countries. Working Paper No. 38, Oxford Poverty \& Human Development Initiative, Oxford, UK. http://dx.doi.org/10.2139/ssrn.1815243

Barrow, E., J. Kamugisha-Ruhombe, I. Nhantumbo, R. Oyono, and M. Savadogo. 2016. Who owns Africa's forests? Exploring the impacts of forest tenure reform on forest ecosystems and livelihoods. Forests, trees and livelihoods 25:132-156. http://dx.doi. org/10.1080/14728028.2016.1159999

Bates, D., M. Mächler, B. Bolker, and S. Walker. 2015. Fitting linear mixed-effects models using lme4. Journal of Statistical Software 67:1-48. http://dx.doi.org/10.18637/jss.v067.i01

Beauchamp, E., and V. Ingram. 2011. Impacts of community forests on livelihoods in Cameroon: lessons from two case studies. International Forestry Review 13:389-403. http://dx.doi. org/10.1505/146554811798811371

Blomley, T., and S. Iddi. 2009. Participatory forest management in Tanzania: 1993-2009 Lessons learned and experiences to date. Ministry of Natural Resources and Tourism, Forestry and Beekeeping Division, Dar es Salaam, Tanzania.

Brown, H. C. P., and J. P. Lassoie. 2010. Institutional choice and local legitimacy in community-based forest management: lessons learned from Cameroon. Environmental Conservation 37:261-269. http://dx.doi.org/10.1017/S0376892910000603

Brunette, W., M. Sundt, N. Dell, R. Chaudhri, N. Breit, and G. Borriello. 2013. Open data kit 2.0: expanding and refining information services for developing regions. In Proceedings of the 14th Workshop on Mobile Computing Systems and Applications. Jekyll Island, Georgia, USA. http://dx.doi.org/10.1145/2444776.2444790

Christensen, R. H. B. 2015. Ordinal-regression models for ordinal data. Pages 6-28 R package version 2015. The R Project for Statistical Computing, Vienna, Austria.

Daw, T., K. Brown, S. Rosendo, and R. Pomeroy. 2011. Applying the ecosystem services concept to poverty alleviation: the need to disaggregate human well-being. Environmental Conservation 38:370-379. http://dx.doi.org/10.1017/S0376892911000506

Garrett, B. L. 2010. Videographic geographies: using digital video for geographic use. Progress in Human Geography 35:4.

Gurney, G. G., J. Cinner, N. C. Ban, R. L. Pressey, R. Pollnac, S. J. Campbell, S. Tasidjawa, and F. Setiawan. 2014. Poverty and protected areas: an evaluation of a marine integrated conservation and development project in Indonesia. Global Environmental Change 26:98-107. http://dx.doi.org/10.1016/j. gloenvcha.2014.04.003

Lund, J. F., and M. Saito-Jensen. 2013. Revisiting the issue of elite capture of participatory initiatives. World Development 46:104-112. http://dx.doi.org/10.1016/j.worlddev.2013.01.028

Mahajan, S. L., and T. Daw. 2016. Perceptions of ecosystem services and benefits to human well-being from community-based marine protected areas in Kenya. Marine Policy 74:108-119. http://dx.doi.org/10.1016/j.marpol.2016.09.005

Makwarimba, M., and P. Ngowi. 2012. Making land investment work for Tanzania: scoping assessment for multi-stakeholder dialogue initiative. Tanzania Natural Resource Forurm, IIED, and REPOA, Dar es Salaam, Tanzania. [online] URL: http://www. tnrf.org/LBI-report.pdf

Ministry of Natural Resources and Tourism (MNRT). 2012. Participatory forest management in Tanzania facts and figures. MNRT, Dar es Salaam, Tanzania.

Ministry of Natural Resources and Tourism (MNRT). 2015. National forest resources monitoring and assessment of Tanzania 
mainland: main results. MNRT, Tanzania Forest Services, Government of Finland, FAO, Dar es Salaam, Tanzania.

Mpingo Conservation and Development Initiative (MCDI). 2015. Mpingo Conservation and Development Initiative annual report 2014-15. MCDI, Kilwa Masoko, Tanzania.

Mustalahti, I., and O. S. Rakotonarivo. 2014. REDD+ and empowered deliberative democracy: learning from Tanzania. World Development 59:199-211. http://dx.doi.org/10.1016/j. worlddev.2014.01.022

Nelson, F., and A. Agrawal. 2008. Patronage or participation? Community-based natural resource management reform in subSaharan Africa. Development and Change 39:557-585. http://dx. doi.org/10.1111/j.1467-7660.2008.00496.x

Odera, J. 2004. Lessons learnt on community forest management in Africa. Lessons learnt on sustainable forest management in Africa. KSLA/AFORNET/FAO, Nairobi, Kenya.

Patenaude, G., and K. Lewis. 2014. The impacts of Tanzania's natural resource management programmes for ecosystem services and poverty alleviation. International Forestry Review 16:459-473. http://dx.doi.org/10.1505/146554814813484077

Persha, L., and C. Meshack. 2015. Is Tanzania's joint forest management program a triple win? Understanding causal pathways for livelihoods, governance and forest condition impacts. International Initiative for Impact Evaluation (3ie), New Delhi, India.

Porter-Bolland, L., E. A. Ellis, M. R. Guariguata, I. Ruiz-Mallén, S. Negrete-Yankelevich, and V. Reyes-Garcia. 2012. Community managed forests and forest protected areas: an assessment of their conservation effectiveness across the tropics. Forest Ecology and Management 268:6-17. http://dx.doi.org/10.1016/j.foreco.2011.05.034

Rao, V., and A. Ibanez. 2001. The social impact of social funds in Jamaica: a mixed-methods analysis of participation, targeting and collective action in community driven development. The World Bank, Washington, D.C., USA

Ribot, J. 2004. Waiting for democracy: the politics of choice in natural resource decentralization. World Resources Institute, Washington, D.C., USA.

RStudio_Team. 2015. RStudio: Integrated development environment for R. RStudio, Boston, Massachusetts, USA.

Schlager, E., and E. Ostrom. 1992. Property-rights regimes and natural resources: a conceptual analysis. Land Economics 68:249-262. http://dx.doi.org/10.2307/3146375

Scott, K. 2012. Measuring wellbeing: towards sustainability? Routledge, Oxon, UK.

Sen, A. 1999. Development as freedom. Oxford University Press, Oxford, UK.

Seymour, F., T. La Vina, and K. Hite. 2014. Evidence linking community level tenure and forest condition: an annotated bibliography. Climate and Land Use Alliance, San Francisco, USA.

Shackleton, S., B. Campbell, E. Wollenberg, and D. Edmunds. 2002. Devolution and community-based natural resource management: creating space for local people to participate and benefit? Natural resource perspectives. The Overseas Development Initiative, London, UK.

Snowden, D. 1998. Eyes see; ears hear. Pages 60-73 in D. Richardson and L. Paisley, editors. The first mile of connectivity. Food and Agriculture Organization, Rome, Italy.

Sunderlin, W. D., J. Hatcher, and M. Liddle. 2008. From exclusion to ownership? Challenges and opportunities in advancing forest tenure reform. Rights and Resources Initiative, Washington, D. C., USA.

United Republic of Tanzania (URT). 2007. The land use planning act. URT, Dar es Salaam, Tanzania.

United Republic of Tanzania (URT). 2013. National strategy for reduced emissions from deforestation and forest degradation $(R E D D+)$. United Republic of Tanzania Vice President's Office, Dar es Salaam, Tanzania.

World Bank. 2008. CDD and elite capture: reframing the conversation. The World Bank, Washington, D.C., USA.

Woodhouse, E., K. Homewood, E. Beauchamp, T. Clements, J. T. McCabe, D. Wilkie, and E. J. Milner-Gulland. 2015. Guiding principles for evaluating the impacts of conservation interventions on human well-being. Philosophical Transactions of the Royal Society B: Biological Sciences 370:1-11. http://dx.doi. org/10.1098/rstb.2015.0103 
Appendix 1. Questionnaire.

Only households that formed at 2005 (or earlier) are eligible for this interview, determined in the wealth-ranking exercise. Forty households in each village will be interviewed. Households will be selected combining a stratified and random and purposive manner:

- Begin by selecting 3-5 households from the very poor and rich categories, respectively.

- Then select the VEO, VC chairperson, up to 4 sub-village chairs, up to 7 VNRC/ environmental committee leaders, and top off the balance to 15 people from VC representatives.

- $\quad 12-15$ poor and normal households

The 'household head' should generally be interviewed in private. Every other household should interview the wife of the household head, assuming that the head is male (if a polygamist household, try to interview the first wife. If she is not available, try the second, etc. HOWEVER, recall that the household head must have formed at 2005 or earlier to qualify for an interview).

\section{General guidelines}

- Begin each interview by introducing yourself followed by a description of the project and research objectives

- The interview will specifically involve a series of questions about the respondent's household and how (if) it has changed since 2005 to present day (2015)

- Indicate that any information given is kept anonymous and may not be traced back to the individual. Make clear that they have every right to decline to be interviewed or to decline to answer any particular question and/or withdraw and cease the interview at any point in the process.

- At the end of the study towards the end of 2016, results will be disseminated to the village

- Request their consent to be interviewed

- Should take between 1-3 hours of their time for which we will compensate them 
Does the respondent consent to participate in the interview? (Tick appropriate box)

\begin{tabular}{|l|l|}
\hline Yes & No \\
\hline
\end{tabular}

If no, cease the interview.

Because some of the questions will require the respondent to reflect back to 2005, it is worthwhile spending a few minutes asking them to reflect back to this time to see if there are any distinct events - personal or at a larger scale, that help them refer back to this time, e.g. birth of a child, natural event such as flooding. A significant national event in 2005 that may help stimulate this was the presidential election.

Is the respondent able to recall events and the circumstances of his/ her livelihood around 2005? (Tick appropriate box)

\begin{tabular}{|l|l}
\hline Yes & No
\end{tabular}

\section{General}

\begin{tabular}{|l|l|}
\hline 1.1 Date (DD/MM/YYYY) & \\
\hline 1.2 Time at beginning of interview (24 hour) & \\
\hline 1.3 Household ID (linked to wealth ranking) & \\
\hline 1.4 Village & \\
\hline 1.5 CBNRM Present (yes = 1, no $=0$ ) & \\
\hline 1.6 Interviewer (initials) & \\
\hline 1.7 GPS Coordinates (Lat/Long) & \\
\hline
\end{tabular}

\section{Household demographics}

\begin{tabular}{|l|l|}
\hline 2.1 Who is being interviewed? (HH head $=1$, wife of HH head $=2$ ) & \\
\hline 2.2 If from a polygamist HH, which number wife are you? & \\
\hline $\begin{array}{l}2.2 \mathrm{~b} \text { How many wives do you have? [If one of the wives] How } \\
\text { many wives does your husband have? }\end{array}$ & \\
\hline 2.3 Gender of HH head (Circle one) & Male / Female \\
\hline $\begin{array}{l}\text { years }=3,40-49 \text { years }=4,50-59 \text { years }=5,60-69 \text { years }=6,70-79 \\
\text { years }=7,80-89 \text { years }=8, \text { more than } 89 \text { years }=9 \text { ) }\end{array}$ & \\
\hline $\begin{array}{l}2.5 \text { Marital status (married }=1 \text {, divorced/ separated }=2, \text { widow }= \\
3, \text { single }=4 \text { ) }\end{array}$ & \\
\hline $\begin{array}{l}2.6 \text { Highest level of education in household } \\
\text { (number of years of schooling completed) (less than } 5 \text { years }=0,\end{array}$ & \\
more than 5 years $=1$ ) & \\
\hline $\begin{array}{l}2.7 \text { Has anyone in your household completed secondary school? } \\
\text { (yes }=1, \text { no }=0 \text { ) }\end{array}$ & \\
\hline $\begin{array}{l}2.8 \text { Has anyone in your household completed a bachelor's degree? } \\
\text { (yes }=1, \text { no }=0 \text { ) }\end{array}$ & \\
\hline $\begin{array}{l}2.9 \text { Does anyone in your household have vocational training? } \\
\text { (yes }=1, \text { no }=0 \text { ) }\end{array}$ & \\
\hline $\begin{array}{l}2.10 \text { If yes, is this training from a recognized institution? } \\
\text { (yes }=1, \text { no }=0 \text { ) }\end{array}$ & \\
\hline $\begin{array}{l}2.11 \text { Number of years the household has been present in the } \\
\text { village }\end{array}$ & \\
\hline 2.12 Ethnicity (Tribe) of interviewee & \\
\hline
\end{tabular}




\begin{tabular}{|c|c|c|}
\hline \multicolumn{3}{|l|}{$\begin{array}{l}\text { 2.13 Religion of interviewee (Muslim }=1 \text {, Christian/ Catholic/ } \\
\text { Pentecost }=2 \text {, Customary religion }=3 \text { ) }\end{array}$} \\
\hline \multicolumn{3}{|l|}{$\begin{array}{l}\text { 2.14 Political affiliation of interviewee } \\
(\mathrm{CCM}=1, \mathrm{CUF}=2, \text { Chadema }=3 \text {, Other }=4)\end{array}$} \\
\hline \multicolumn{3}{|l|}{$\begin{array}{l}2.15 \text { Now, how old are your children? [Record the number of } \\
\text { children between the ages of 7-14 years] }\end{array}$} \\
\hline \multicolumn{3}{|l|}{ 2.16 Now, how many of your children are in primary school? } \\
\hline \multicolumn{3}{|l|}{$\begin{array}{l}2.17 \text { In } 2005 \text {, how old were your children? [Record the number of } \\
\text { children between the ages of } 7-14 \text { years] }\end{array}$} \\
\hline \multicolumn{3}{|l|}{$2.18 \ln 2005$, how many of your children were in primary school? } \\
\hline $\begin{array}{l}2.19 \text { How many people do you provide for? (This would include } \\
\text { anyone that lives in the household the majority of the year such as } \\
\text { servants, labourers, etc.) }\end{array}$ & NOW (a) & In 2005 (b) \\
\hline
\end{tabular}

\section{House/ Residence}

\begin{tabular}{|c|c|c|}
\hline & Now (a) & In 2005 (b) \\
\hline 3.1 Do you have a house? Code 1 & & \\
\hline $\begin{array}{l}3.2 \text { Have you managed to make improvements to your house? } \\
\text { Code } 1\end{array}$ & & \\
\hline $\begin{array}{l}\text { 3.3 What is the floor of your house made of? (dirt, sand, dung }=0 \text {, } \\
\text { tile or cement }=1 \text { ) }\end{array}$ & & \\
\hline 3.4 Do you have (mains) electricity? Code 1 & & \\
\hline 3.5 Do you have solar electricity? Code 1 & & \\
\hline $\begin{array}{l}\text { 3.6 What kind of toilet do you have? }(0=\text { any toilet that is shared } \\
\text { by more than one household and/ or with a shallow pit, } 1=\text { an } \\
\text { unshared, deep pit latrine, } 2 \text { = an unshared, porcelain 'water' } \\
\text { toilet) }\end{array}$ & & \\
\hline $\begin{array}{l}3.7 \text { Where do you collect you drinking water? How far is the source } \\
\text { from your house (minutes roundtrip)? } \\
\text { (more than or equal to } 30 \text { minutes }=0 \text {, less than } 30 \text { minutes AND } \\
\text { from a piped, public tap, borehole, pump, protected well, spring or } \\
\text { rainwater (ie NOT from a river) }=1 \text { ) }\end{array}$ & & \\
\hline $\begin{array}{l}\text { 3.8 What do you primarily use for cooking fuel? (dung, wood or } \\
\text { charcoal }=0 \text {, cooking gas }=1 \text { ) }\end{array}$ & & \\
\hline
\end{tabular}

Code 1: yes $=1$, no $=0,777=$ refuses to answer, $888=$ does not apply, $999=$ does not know 


\section{Ardhi (Land)}

4.1 Does your household (customarily) own any land? ['Customarily' would include any land that a household has cleared themselves, has been passed down to them by their parents, or otherwise purchased. The land is still, however, properly owned by the government of TZ]
(a) Now
(b) In 2005

Code: yes $=1$, no $=0,777=$ refuses to answer, $888=$ does not apply, $999=$ does not know

4.2 How much land does your household (customarily) own now?

ha, acres, $\mathrm{m} 2$, ft2 (Circle appropriate)

4.3 Does your household rent any land now or any time since 2005?

\begin{tabular}{|l|l|}
\hline Yes & No \\
\hline
\end{tabular}

4.4 How much land does your household rent?

ha, acres, $\mathrm{m} 2$, ft2 (Circle appropriate)

4.5 Has the amount of land that you own and/ or rent changed since 2005, if yes please explain why, e.g. inheritance of land from deceased family member, increase of income enabled the purchase of more land, poor income required sale of some land, difficulty in expanding due to (forest) land management, etc.

4.6a Does the harvest from the land that you own and/ or rent provide enough income to enable you to feed your household on a yearly basis?

(yes $=1$, no $=0$ )

\begin{tabular}{|l|l|}
\hline (a) Now & (b) In 2005 \\
\hline & \\
\hline
\end{tabular}

4.6b If the harvest from the land that you own and/ or rent is not sufficient to feed your family on a yearly basis, explain why?

4.7 If 'no', how many months of the year can your harvest feed your household? (0-12 months/ If two values are provided by the respondent record the lower of the two.)

\begin{tabular}{|l|l|}
\hline (a) Now & (b) $\ln 2005$ \\
\hline & \\
\hline
\end{tabular}

4.8 Is the land that you own and rent sufficient to feed your household and earn some extra income on a yearly basis? (yes $=1$, no $=0$ )
(a) Now
(b) In 2005 
I am going to read out a list of items. For each once, tell me if you use this item or anyone in your household does now or in 2005.

\begin{tabular}{|l|l|l|}
\hline Use the following in your fields: & Now (a) & 2005 (b) \\
\hline 4.9 animal manure & & \\
\hline 4.10 Chemical fertilizers & & \\
\hline 4.11 Pesticides (purchased) & & \\
\hline 4.12 Improved seeds & & \\
\hline 4.13 Kibarua Labourers/ Hired help & & \\
\hline 4.14 Irrigation & & \\
\hline & & \\
\hline & & \\
\hline
\end{tabular}

Code: yes $=1$, no $=0,777=$ refuses to answer, $888=$ does not apply, $999=$ does not know

4.15 How do you see your ability to provide food for yourself and your household NOW as compared to 2005 ?

Code: much worse now $=1$, worse now $=2$, no

change $=3$, better now $=4$, much better now $=5$

4.16 If there has been a change in your ability to provide food for yourself and your household, please describe WHY? What has made it more or less difficult, eg new constraints on land, the size of my family has grown, more people have moved here, etc. Can you define what has been the MAIN cause of this change?

4.17 Do you experience crop raiding?

Now (a) $\quad$ In 2005 (b)

Code: yes $=1$, no $=0,777=$ refuses to answer, $888=$ does not apply, $999=$ does not know

4.18 How do you see the level of crop raiding you experience NOW as compared to 2005?

Code: much worse now $=1$, worse now $=2$, no

change $=3$, better now $=4$, much better now $=5$

4.19 What is the main cause of this change in crop raiding? 


\section{Livestock}

5.1 Do you keep any livestock NOW? (yes $=1$, no $=0$ )

How has the number of animals you own changed from 2005 to now?

(many less $=1$, less $=2$, no change $=3$, more $=4$, or many more $=5$ )

\begin{tabular}{|l|l|}
\hline $\begin{array}{l}\text { 5.2 Cows (includes males and } \\
\text { females) }\end{array}$ & \\
\hline 5.3 Oxen (working animals) & \\
\hline 5.4 Chickens/ Other birds & \\
\hline 5.5 Goats/ Sheep & \\
\hline 5.6 Pigs & \\
\hline 5.7 Donkeys & \\
\hline
\end{tabular}

5.8 If the number of your animals has changed, what is the main cause of this? 


\section{Income/ Livelihoods/ Assets}

Where does most of your household's income come from? Or, worded differently, what does your family do to sustain itself? [Rank in order of importance with ' 1 ' being the most important] Describe the proportion of income coming from the top 5 sources $-* * *$ NOTE: I would expect most people to describe agricultural production as their main source of income $* * *$

Code: agriculture $=1$, livestock $=2$, small business $=3$, remittance from family or other person $=4$, sale of items collected from the forest $=5$, household consumption of items collected from the forest $=6$, casual labourer $=7$, or regular waged job $=8$ (ie in a shop or office).

6.1a in 2015 Rank 1

6.2a in 2015 Rank 2

6.3a in 2015 Rank 3

6.4a in 2015 Rank 4

6.5a in 2015 Rank 5

$6.1 \mathrm{~b}$ in 2005 Rank 1

$6.2 \mathrm{~b}$ in 2005 Rank 2

$6.3 \mathrm{~b}$ in 2005 Rank 3

$6.4 \mathrm{~b}$ in 2005 Rank 4

$6.5 \mathrm{~b}$ in 2005 Rank 5

I am going to read a list of items. Please tell me if you or anyone in your household has the following:

\begin{tabular}{|l|l|l|}
\hline & Now (a) & $\ln 2005(\mathrm{~b})$ \\
\hline 6.6 Mobile phone & & \\
\hline 6.7 Radio & & \\
\hline 6.8 Television & & \\
\hline 6.9 Motorbike & & \\
\hline 6.10 Tractor or powertiller & & \\
\hline 6.11 Metal roof & & \\
\hline 6.12 Bicycle & & \\
\hline 6.31 Solar light & & \\
\hline
\end{tabular}

Code: yes $=1$, no $=0,777=$ refuses to answer, $888=$ does not apply, $999=$ does not know 


\section{Forest}

I am going to read a list of products from the forest. For each one, tell me if you or any one in your household collects this product now or in 2005.

\begin{tabular}{|l|l|l|}
\hline & Now (a) & $\ln 2005(\mathrm{~b})$ \\
\hline 7.1 Medicinal plants & & \\
\hline 7.2 Wild honey & & \\
\hline 7.3 Firewood & & \\
\hline 7.4 Charcoal production & & \\
\hline 7.5 Wood for construction - eg poles & & \\
\hline 7.6 Thatch - grass for roofing, etc. & & \\
\hline 7.7 Forest fruit or other edible plant foods including mushrooms & & \\
\hline 7.8 Fish & & \\
\hline 7.9 Wild meat & & \\
\hline & & \\
\hline & & \\
\hline
\end{tabular}

Code: yes $=1$, no $=0,777=$ refuses to answer, $888=$ does not apply, $999=$ does not know

7.10 If there have been any changes in your household's collection of the forest products above since 2005, please describe the MAIN reason WHY you think there is this change?

How do you see your access (not availability) to the following resources for you and your household NOW as compared to 2005 ?

[NOTE: I am interested in 'access' here, being able to go to a location and collect it, but NOT interested in whether the resource is more or less available.]

\begin{tabular}{|l|l|}
\hline & Access NOW compared to 2005 \\
\hline 7.11 Land for settlement & \\
\hline 7.12 Land for cultivation & \\
\hline 7.13 Land for grazing livestock & \\
\hline 7.14 Firewood & \\
\hline 7.15 Construction materials & \\
\hline 7.16 Water & \\
\hline
\end{tabular}

Code: much worse now $=1$, worse now $=2$, no change $=3$, better now, $4=$ much better now $=5$

7.17 If there has been a change in access since 2005, please describe the MAIN reason WHY you think this change has occurred? [Be sure to indicate in your recorded response what the respondent is referring to, eg land for settlement has gotten worse due to ... ] 
It is important to conserve the forest because. . .

\begin{tabular}{|c|c|c|c|c|c|}
\hline & $\begin{array}{l}\text { Strongly } \\
\text { agree }\end{array}$ & Agree & $\begin{array}{l}\text { In the } \\
\text { middle }\end{array}$ & Disagree & $\begin{array}{l}\text { Strongly } \\
\text { disagree }\end{array}$ \\
\hline $\begin{array}{l}7.18 \text { it is a source of things } \\
\text { that are important and } \\
\text { useful to our daily lives like } \\
\text { water, food and medicinal } \\
\text { plants }\end{array}$ & $\begin{array}{l}\text { Strongly } \\
\text { agree }\end{array}$ & Agree & $\begin{array}{l}\text { In the } \\
\text { middle }\end{array}$ & Disagree & $\begin{array}{l}\text { Strongly } \\
\text { disagree }\end{array}$ \\
\hline $\begin{array}{l}7.19 \text { it is a place where we } \\
\text { conduct certain rituals that } \\
\text { are important for our } \\
\text { culture/ people }\end{array}$ & $\begin{array}{l}\text { Strongly } \\
\text { agree }\end{array}$ & Agree & $\begin{array}{l}\text { In the } \\
\text { middle }\end{array}$ & Disagree & $\begin{array}{l}\text { Strongly } \\
\text { disagree }\end{array}$ \\
\hline $\begin{array}{l}7.20 \text { it is a legacy for our } \\
\text { children/ grandchildren }\end{array}$ & $\begin{array}{l}\text { Strongly } \\
\text { agree }\end{array}$ & Agree & $\begin{array}{l}\text { In the } \\
\text { middle }\end{array}$ & Disagree & $\begin{array}{l}\text { Strongly } \\
\text { disagree }\end{array}$ \\
\hline $\begin{array}{l}7.21 \text { the government tells us } \\
\text { to } \\
\text { serikali imetuambia }\end{array}$ & $\begin{array}{l}\text { Strongly } \\
\text { agree }\end{array}$ & Agree & $\begin{array}{l}\text { In the } \\
\text { middle }\end{array}$ & Disagree & $\begin{array}{l}\text { Strongly } \\
\text { disagree }\end{array}$ \\
\hline $\begin{array}{l}7.22 \text { it is God's will } \\
\text { ni mambo ya Mungu }\end{array}$ & $\begin{array}{l}\text { Strongly } \\
\text { agree }\end{array}$ & Agree & $\begin{array}{l}\text { In the } \\
\text { middle }\end{array}$ & Disagree & $\begin{array}{l}\text { Strongly } \\
\text { disagree }\end{array}$ \\
\hline \multirow[t]{2}{*}{$\begin{array}{l}7.23 \text { the forest is our mother } \\
\text { msitu ni mama yetu }\end{array}$} & $\begin{array}{l}\text { Strongly } \\
\text { agree }\end{array}$ & Agree & $\begin{array}{l}\text { In the } \\
\text { middle }\end{array}$ & Disagree & $\begin{array}{l}\text { Strongly } \\
\text { disagree }\end{array}$ \\
\hline & $\begin{array}{l}\text { Strongly } \\
\text { agree }\end{array}$ & Agree & $\begin{array}{l}\text { In the } \\
\text { middle }\end{array}$ & Disagree & $\begin{array}{l}\text { Strongly } \\
\text { disagree }\end{array}$ \\
\hline
\end{tabular}

Do you agree with the following?

\begin{tabular}{|c|c|c|c|c|c|}
\hline $\begin{array}{l}7.24 \text { It is good to use natural } \\
\text { resources from the forest to } \\
\text { try to become richer. } \\
\mathrm{Ni} \text { vizuri kutumia mali asili } \\
\text { kujipatia utajiri (oa faidha ?) }\end{array}$ & $\begin{array}{l}\text { Strongly } \\
\text { agree }\end{array}$ & Agree & $\begin{array}{l}\text { In the } \\
\text { middle }\end{array}$ & Disagree & $\begin{array}{l}\text { Strongly } \\
\text { disagree }\end{array}$ \\
\hline $\begin{array}{l}7.25 \text { The needs of the } \\
\text { community should come } \\
\text { before the needs of } \\
\text { individuals } \\
\text { Maslahi ya jamii kwanza } \\
\text { alafu ndio maslahi binafsi }\end{array}$ & $\begin{array}{l}\text { Strongly } \\
\text { agree }\end{array}$ & Agree & $\begin{array}{l}\text { In the } \\
\text { middle }\end{array}$ & Disagree & $\begin{array}{l}\text { Strongly } \\
\text { disagree }\end{array}$ \\
\hline
\end{tabular}

7.26 Is anyone in your household currently (in 2015) on the Village Council, VNRC or some other committee that is part of the VC?

$($ yes $=1$, no $=0)$ 
7.27 If yes, how many years has s/he been on the Village Council? (If less than a year, write ' 0 ')

7.28 Do you attend Village Assembly meetings regularly?

\begin{tabular}{|l|l}
\hline (a) Now & (b) In 2005
\end{tabular}

(yes $=1$, no $=0$ )

7.29 Why do you attend these meetings 


\section{CBFM Villages only}

7.30 Do you know anything about the VLFR? (NOTE: I want to ensure that the person is aware that there is an established VLFR and that any income generated from the VLFR should, technically, be put towards community development activities)

Yes $=1$, No $=0$

7.31 Do you know what part of the forest is included in the CBFM? (NOTE: In areas with CBFM and JFM be sure the respondent is able to distinguish. If not, put does not know, '999').

Yes $=1$, No $=0$

7.32 Do you feel sufficiently informed about the management of the CBFM?

Yes $=1$, No $=0$

7.33 Did you agree to the formation of the CBFM?

Yes $=1$, No $=0$

7.34 Are you in favour of the presence of a CBFM in your village today?

Yes $=1$, No $=0$

7.35 If your support of the CBFM has changed since its formation to today, please describe why.

7.36 Do you or anyone in your household receive employment or other financial benefit from the CBFM?

Yes $=1$, No $=0$

7.37 Do you know who the CBFM village representatives are?

Yes $=1$, No $=0$

7.38 Do you feel you are able to exert influence on the CBFM management through your village representatives?

Yes $=1$, No $=0$ 


\section{Health}

[NOTE: This section should be prefaced with an acknowledgement that the questions are sensitive but important and helpful in bringing awareness to the authorities of the level of health care in the community. Also reiterate that it is the respondent's choice whether or not to answer the questions.]

8.1 Do you have health insurance? (yes $=1$, no $=0$ )

Now

8.2 Is there an operational dispensary in your village? (I define a 'dispensary' where there is a nurse or doctor on a regular basis, eg weekly, monthly, etc.)

\begin{tabular}{|l|l|}
\hline (a) Now & (b) $\ln 2005$ \\
\hline
\end{tabular}
$($ yes $=1$, no $=0$ )

8.3 How accessible is the nearest hospital NOW as compared to 2005? How easy is it to get to? Code: much more accessible $=1$, more accessible $=2$, no change $=3$, more difficult to reach $=4$, much more difficult to reach $=5$

8.4 Has anyone in your household ever lost a child (death)? [A child refers to someone up to the age of 18]

(yes $=1$, no $=0)$

8.5 Would you like to tell us what happened? 


\section{Self-esteem/ Hope/ Agency}

\section{Snyder Hope Scale}

Score each statement as follows:

$1=$ Definitely false, $2=$ mostly false, $3=$ mostly true, or $4=$ definitely true

\begin{tabular}{|l|l|}
\hline 9.1 Are you someone that thinks there are many ways to get out of a jam? \\
Mimi ninaweza kufikiria juu ya njia mbalimbali za kujikwamua kutoka katika hali \\
ngumu iwapo maisha yatabadilika bila kutegemea.
\end{tabular}

(Snyder et al., 1991, p. 585 - see also Barnett et al 2015 Global Public Health paper) Swahili translation provided by colleague of Janet Seeley's, Shelley Lees and Kija Nyatali (March 2014) 
Do you feel that your voice is heard/respected in decisions made in your household about (Circle one for each statement)

\begin{tabular}{|l|l|l|l|l|l|l|}
\hline 9.13 Education for my children & $\begin{array}{l}\text { Strongly } \\
\text { agree }\end{array}$ & Agree & $\begin{array}{l}\text { In the } \\
\text { middle }\end{array}$ & Disagree & $\begin{array}{l}\text { Strongly } \\
\text { disagree }\end{array}$ & $\begin{array}{l}\text { Does } \\
\text { not } \\
\text { apply }\end{array}$ \\
\hline 9.14 Livestock & $\begin{array}{l}\text { Strongly } \\
\text { agree }\end{array}$ & Agree & $\begin{array}{l}\text { In the } \\
\text { middle }\end{array}$ & Disagree & $\begin{array}{l}\text { Strongly } \\
\text { disagree }\end{array}$ & $\begin{array}{l}\text { Does } \\
\text { not } \\
\text { apply }\end{array}$ \\
\hline 9.15 Money & $\begin{array}{l}\text { Strongly } \\
\text { agree }\end{array}$ & Agree & $\begin{array}{l}\text { In the } \\
\text { middle }\end{array}$ & Disagree & $\begin{array}{l}\text { Strongly } \\
\text { disagree }\end{array}$ & $\begin{array}{l}\text { Does } \\
\text { not } \\
\text { apply }\end{array}$ \\
\hline
\end{tabular}

Do you feel that your voice is heard/respected in decisions made in your village about (Circle one for each category)

\begin{tabular}{|l|l|l|l|l|l|l|}
\hline 9.16 Land & $\begin{array}{l}\text { Strongly } \\
\text { agree }\end{array}$ & Agree & $\begin{array}{l}\text { In the } \\
\text { middle }\end{array}$ & Disagree & $\begin{array}{l}\text { Strongly } \\
\text { disagree }\end{array}$ & $\begin{array}{l}\text { Does } \\
\text { not } \\
\text { apply }\end{array}$ \\
\hline 9.17 Village funds & $\begin{array}{l}\text { Strongly } \\
\text { agree }\end{array}$ & Agree & $\begin{array}{l}\text { In the } \\
\text { middle }\end{array}$ & Disagree & $\begin{array}{l}\text { Strongly } \\
\text { disagree }\end{array}$ & $\begin{array}{l}\text { Does } \\
\text { not } \\
\text { apply }\end{array}$ \\
\hline
\end{tabular}

Circle one for each statement.

\begin{tabular}{|l|l|l|l|l|l|l|}
\hline $\begin{array}{l}\text { 9.18 I have authority to make } \\
\text { decisions which impact on my life. }\end{array}$ & $\begin{array}{l}\text { Strongly } \\
\text { agree }\end{array}$ & Agree & $\begin{array}{l}\text { In the } \\
\text { middle }\end{array}$ & Disagree & $\begin{array}{l}\text { Strongly } \\
\text { disagree }\end{array}$ & $\begin{array}{l}\text { Does } \\
\text { not } \\
\text { apply }\end{array}$ \\
\hline $\begin{array}{l}\text { 9.19 I feel safe and secure In my } \\
\text { home. }\end{array}$ & $\begin{array}{l}\text { Strongly } \\
\text { agree }\end{array}$ & Agree & $\begin{array}{l}\text { In the } \\
\text { middle }\end{array}$ & Disagree & $\begin{array}{l}\text { Strongly } \\
\text { disagree }\end{array}$ & $\begin{array}{l}\text { Does } \\
\text { not } \\
\text { apply }\end{array}$ \\
\hline $\begin{array}{l}\text { 9.20 I feel safe and secure in my } \\
\text { village. }\end{array}$ & $\begin{array}{l}\text { Strongly } \\
\text { agree }\end{array}$ & Agree & $\begin{array}{l}\text { In the } \\
\text { middle }\end{array}$ & Disagree & $\begin{array}{l}\text { Strongly } \\
\text { disagree }\end{array}$ & $\begin{array}{l}\text { Does } \\
\text { not } \\
\text { apply }\end{array}$ \\
\hline $\begin{array}{l}\text { 9.21 I feel safe and secure in the } \\
\text { forest in and around my village. }\end{array}$ & $\begin{array}{l}\text { Strongly } \\
\text { agree }\end{array}$ & Agree & $\begin{array}{l}\text { In the } \\
\text { middle }\end{array}$ & Disagree & $\begin{array}{l}\text { Strongly } \\
\text { disagree }\end{array}$ & $\begin{array}{l}\text { Does } \\
\text { not } \\
\text { apply }\end{array}$ \\
\hline
\end{tabular}

\begin{tabular}{|l|l|l|l|l|l|l|}
\hline $\begin{array}{l}\text { 9.22 My voice is equal to that of my } \\
\text { spouse }\end{array}$ & $\begin{array}{l}\text { Strongly } \\
\text { agree }\end{array}$ & Agree & $\begin{array}{l}\text { In the } \\
\text { middle }\end{array}$ & Disagree & $\begin{array}{l}\text { Strongly } \\
\text { disagree }\end{array}$ & $\begin{array}{l}\text { Does } \\
\text { not } \\
\text { apply }\end{array}$ \\
\hline
\end{tabular}

9.23 If you disagree with 9.22 (only), please explain WHY? 
9.24 Did you know about this research project before this interview?

9.25 If yes, how did you hear about it? [Code 2]

9.26 [PV villages only - Mchakama, Kilambo, Kinyawnganga] Were you aware of the participatory video?

9.27If yes, have you watched the participatory video?

Code 1: yes $=1$, no $=0$

Code 2: Village assembly meeting $=1$, word-of-mouth $=2$, participatory video $=3$, interviewed earlier $=4$, Other $=5$

\section{Enumerator assessment of the interviewee}

How reliable is the information generally provided by the interviewee?

Code: poor $=1$, reasonably reliable $=2$, very reliable $=3$

List the numbers of any sections and/ or questions where you think the respondent's answers are less reliable.

\begin{tabular}{|l|l|}
\hline Section & Question number(s) \\
\hline 2 & \\
\hline 3 & \\
\hline 4 & \\
\hline 5 & \\
\hline 6 & \\
\hline 7 & \\
\hline 8 & \\
\hline 9 & \\
\hline & \\
\hline
\end{tabular}

Enumerator comments (eg problems with specific questions or sections, other notable issues that arose during the interview that may be relevant to data quality)

Time at end of interview 